\title{
Characterization and simulation of rubber derived from tire recycling as a proposal in the development of a solar heater
}

\section{Caracterización y simulación del caucho derivado del reciclaje de neumáticos como propuesta en el desarrollo de un calentador solar}

\author{
AGUILAR-PÉREZ，Silvia-Madai ${ }^{*} ，$ SANCHEZ-RUIZ Francisco-Javier and AGUILAR-PÉREZ \\ Esmeralda
}

Universidad Popular Autónoma del Estado de Puebla

ID $1^{\text {st }}$ Author: Silvia Madai, Aguilar-Pérez / ORC ID: 0000-0002-1603-8201, CVU CONACYT ID: 948410

ID $1^{\text {st }}$ Co-author: Francisco Javier, Sanchez-Ruiz / ORC ID: 0000-0001-6896-5798, CVU CONACYT ID: 169828

ID $2^{\text {nd }}$ Co-author: Esmeralda, Aguilar-Perez / ORC ID: 0000-0001-6794-9630, Researcher ID Thomson: O-3376-2018, CVU CONACYT ID: 625314

DOI: 10.35429/JSL.2021.24.8.7.13

Received March 30 2021; Accepted June 30, 2021

\begin{abstract}
Abstrac
This work shows the experimental procedure to determine and verify the thermal potential of rubber derived from tire recycling in order to characterize the rubber material, through NOM-117-SSA1-1994 and present the components that this material It has, to be incorporated into the design of a prototype of a solar heater, substituting materials, such as glass and / or copper, with which solar heaters are currently composed. As results of this investigation, the rubber material characterization method was carried out, finding $0.190 \mathrm{mg}$ for each gram of recycled rubber of $\mathrm{Cu}$ and $\mathrm{Zn}$, ideal materials for heat transfer; The design of the solar heater prototype was also carried out using SolidWorks ${ }^{\circledR}$ software which provides data and results of the thermal behavior and energy transfer capacity (heat), which was subjected to thermal simulations, obtaining temperatures higher than $80^{\circ} \mathrm{C}$ in each part that makes up the solar heater, which shows that the rubber derived from the recycling of the tire provides a high calorific power of heat transfer to be applied in the elaboration of a solar water heater, which will reduce its production costs and will benefit society by avoiding public health problems such as respiratory diseases due to abrupt changes in temperature.
\end{abstract}

Rubber, simulation, solar heater.

\begin{abstract}
Resumen
El presente trabajo se desarrolló bajo el procedimiento experimental para verificar el potencial térmico del hule derivado del reciclaje de llantas (Pannucharoenwong et al, 2016) (Norambuena-Contreras et al. 2017) con el objetivo de caracterizar el material de caucho, para a través de la NOM-117-SSA1-1994 (SSA, 1995), conocer sus propiedades y componentes que posee este material y ser incorporado en el diseño de un prototipo de calentador solar como sustituto de materiales como el vidrio o el cobre, incorporando el Caucho reciclado, como material idóneo para la elaboración de este producto, también se sometió la propuesta de diseño del calentador solar a una simulación térmica a través del software SolidWork 2018 para medir su comportamiento en condiciones térmicas. Contribuyendo a la línea de investigación del caucho reciclado en su comportamiento térmico y potencial de transferencia de calor, siendo así un sustituto en un producto eficiente, como lo es el calentador de agua, en diferentes hogares.
\end{abstract}

Caucho, Simulación, Calentador solar

Citation: AGUILAR-PÉREZ, Silvia-Madai, SANCHEZ-RUIZ Francisco-Javier and AGUILAR-PÉREZ Esmeralda. Characterization and simulation of rubber derived from tire recycling as a proposal in the development of a solar heater. Journal Simulation and Laboratory. 2021, 8-24: 7-13

*Correspondence to Author (email: jazmind82@ @otmail.com).

$\dagger$ Researcher contributing as first Author. 


\section{Introduction}

Given the accelerated social development and consumerism, the generation of waste in the country triggers the main factors of pollution and effects on natural resources, as well as on living beings (Ospina, 2019). An example of them is the tire, which was designed to withstand mechanical and meteorological conditions within the automobile transport sector (González et al., 2019), which has an average of 5 years in primary useful life (varies according to to the maintenance of the vehicle and the state of the road or routes taken) and it is estimated that it will completely biodegrade for more than 500 years (Española, 2020). According to Forbes (2015), at an international level, 3 billion tires are produced per year; and in Mexico 14.6 million tires per year, with an estimate of 25 million tires discarded annually, of which only $10 \%$ of tires are recycled correctly (INEGI, 2016), with the interest of taking advantage of it in new products and/or articles.

Within the use of recycling in this product, rubber is a compound strongly demanded for its properties in resistance, durability and thermal capacity (Din et al., 2018), considered in the development of new products. Giving the opportunity to new lines of research in the behavior and use of rubber. Taking the foregoing into consideration for this research work, contributions such as et al. (2016), and Norambuena-Contreras et al., (2017) have been considered, which expose the capacity to use and capture the solar energy of the rubber material, derived of tire recycling. The objective of this project is to characterize the rubber material derived from tire recycling through scanning electron microscopy techniques (SEM-XRD) and the simulation of the solar heater prototype through SolidWork software, subjecting it to conditions of force and temperature, to record the behavior of the rubber material. Next, the values obtained with respect to each analysis carried out in the investigation will be detailed.

\section{Rubber derived from tire recycling}

According to Jitjack et al. (2016) the rubber industry is classified into two types: natural rubber industry and rubber production industry; in both, the industry extracts the rubber natural from the tree Hevea Brasiliensis (Ortiz Rodríguez et al., 2020).
Chemically, natural rubber is a polymer of methylbutadiene or isoprene classified within elastomers, characteristic for its elasticity, physical resistance and durability (Peláez et al. 2017). Within the production industry, there is a wide variety of rubbers, among which are:

- Polybutadienes

- $\quad$ Styrene - Butadiene

- $\quad$ Synthetic Polysuprenes

Maintaining in common, the vulcanization process, which provides a wide durability in the products that are made with this material (Mujal et al., 2018).

Sopian et al. (1994) were one of the group of researchers who began to investigate the use of natural rubber as an absorbing material for solar radiation, registering temperatures between $50^{\circ} \mathrm{C}$ and $60^{\circ} \mathrm{C}$ in a water storage tank. Tsilingiris (2000) also established that polyethylene, polypropylene and synthetic rubber are the most suitable materials for use, due to their properties and low acquisition costs to absorb solar radiation. In this context, research on the use of rubber derived from tire recycling opens up the use of this material; Currently, authors such as Pannucharoenwong et al., (2016), Norambuena-Contreras et al. (2017) expose a line of research on materials derived from tires.

\section{Solar water heaters}

For Chevez (2018), the use of solar energy is its capture, they are classified by two systems: systems passives and systems assets. Passive systems are defined as those that do not require any device when capturing solar energy. Active systems are defined as the capture of solar radiation by means of an element called a collector.

Currently there are a wide variety of systems which are replacing the use of fossil fuels with renewable energies, such is the case of solar systems for heating water in homes, institutions, etc. (UNL, 2019) Considering a solar heater system where the radiant energy of the sun is converted into heat, manifested by the increase in temperature of an absorption surface (dark-colored surface). 
This heat obtained from the radiant energy of the sun is transferred by contact with a working fluid, from the solar collector to the hot water tank, directly or indirectly. In Mexico, according to the Official Mexican Standard NOM-027-ENER / SCFI-2018 (Sener, 2018), solar water heaters, both natural circulation or thermosiphonic, are classified as:

a) Self-contained,

b) Collectors with parabolic type concentrators,

c) Composite (CPC),

a) Vacuum tube collectors with or without heat tubes; also with and without reflective surfaces and

b) Flat solar collectors,

And according to your work pressure in:

a) Minimum of: $294.2 \mathrm{kPa}\left(3.0 \mathrm{kgf} / \mathrm{cm}^{2}\right)$ and b) Minimum of: $588.4 \mathrm{kPa}\left(6.0 \mathrm{kgf} / \mathrm{cm}^{2}\right)$

For the present work, the efficiency analysis is developed by means of the simulation of a prototype of a solar vacuum tube heater, made with recycled rubber material from the tire.

\section{Methodology to be developed}

Considering the aforementioned objectives, the present work is carried out under a continuous investigation, implementing an experimental method, where the problem and thematic field of study were identified, focusing on the characteristics of the rubber material, derived from the recycling of the tire.

\section{Characterization of the recycled material}

The principle of the technique used derives from NOM-117-SSA1-1994 (SSA, 1995) for the preparation of the material under the "Sample digestion wet ", the following is done: Add $10 \mathrm{ml}$ of concentrated nitric acid to the solid sample, for this a Kjeldhal flask or flask connected to the refrigerant system is required, it is gently heated without reaching the boiling point, it is recommended to digest the sample 3 hours or longer if necessary for a better resulting sample, once the process is completed, the substrate generated by the digestion is filtered.
Once the sample has been prepared, it will be subjected to the analysis of "Spectroscopy atomic absorption ", method used since 1955 (Razmilic, 2021) in which, The sample solution is directly sucked into a laminar flow flame, in this way the flame generates atoms in its fundamental state of the elements present in the sample and the amount of radiation absorbed will be determined Determining the averages of the amount of metal that exist in the shows.

\section{Prototype simulation by SolidWork 2018}

For the design and elaboration of conditions of the prototype, it is based according to the multifocal analysis methodology of the image, which allows to verify the precise measurements and dimensions of each piece (Rubio et al., 2019). For the simulation, the material of each piece is defined, since it influences the conduction of heat, as well as the initial conditions, such as temperature, convection and ambient temperature.

\section{Results}

For the method of preparing the sample by wet digestion, the digestion with nitric acid was carried out, considering two types of variants: Sample CP100 Crushed (3/4 inch rubber) and Sample CM105 Ground ( $<1 \mathrm{~mm})$. The samples submitted for analysis are presented below Considering polybutadiene rubber which is $27 \%$ and styrene-butadiene 14\%. (Figure 1).

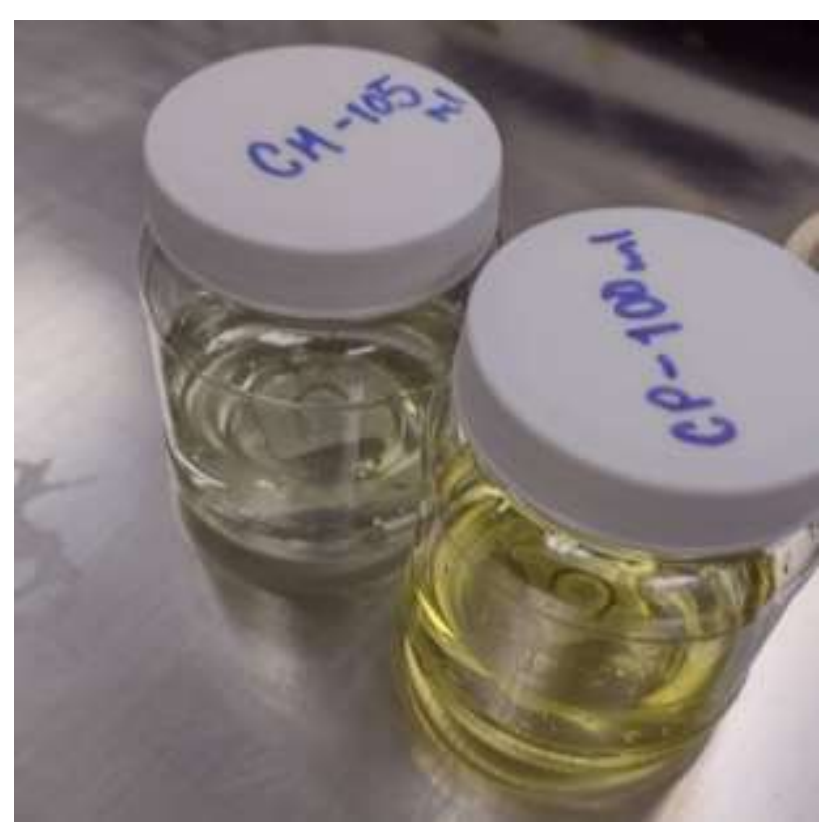

Figure 1 Samples resulting from wet digestion Source: Self Made 
Once the samples were obtained for analysis by atomic absorption spectroscopy, the metals were measured, which are (table 1):

\begin{tabular}{|l|l|}
\hline \multicolumn{1}{|c|}{ Metal } & \multicolumn{1}{c|}{ Symbol } \\
\hline Zinc & $\mathrm{Zn}$ \\
\hline Copper & $\mathrm{Cu}$ \\
\hline Chrome & $\mathrm{Cr}$ \\
\hline Lead & $\mathrm{Pb}$ \\
\hline Cadmium & $\mathrm{Cd}$ \\
\hline Iron & $\mathrm{Fe}$ \\
\hline Nickel & $\mathrm{Ni}$ \\
\hline
\end{tabular}

Table 1 Metals measured within the recycled rubber of the tire

Source: Self Made

Obtaining the following amount of metals in the samples submitted to the method (table 2):

\begin{tabular}{|c|r|r|r|}
\hline \multicolumn{5}{|c|}{ Shredded } \\
\hline \multicolumn{5}{|c|}{ CP100 } \\
\hline Metal & Result (mg/L) & Desv. Standar & $\begin{array}{c}\text { Result } \\
\text { (mg/g rubber) }\end{array}$ \\
\hline $\mathrm{Zn}$ & 109.493 & 0.2021 & 14.460 \\
\hline $\mathrm{Cu}$ & 1.44 & 0.0044 & 0.190 \\
\hline $\mathrm{Cr}$ & 1.059 & 0.0412 & 0.140 \\
\hline $\mathrm{Pb}$ & 0.249 & 0.0042 & 0.033 \\
\hline $\mathrm{Cd}$ & 0.043 & 0.0057 & 0.006 \\
\hline $\mathrm{Fe}$ & 8.204 & 0.028 & 1.083 \\
\hline $\mathrm{Ni}$ & 0.266 & 0.0033 & 0.035 \\
\hline
\end{tabular}

Table 2 Amount of metals obtained in a sample of crushed rubber

Source: Self Made

Which represents a high content of Zinc (Zn) $14.5 \mathrm{mg}$ for each gram of spoon, followed by Iron $(\mathrm{Fe}) 1.09 \mathrm{mg}$ for each gram of rubber, Copper $(\mathrm{Cu}) 0.20 \mathrm{mg}$ for each gram of rubber and Lead $(\mathrm{Pb}) 0.033 \mathrm{mg}$ for every gram of crushed rubber.

Also in the sample of ground rubber the following amounts of metals were obtained (table 3):

\begin{tabular}{|c|r|r|r|}
\hline \multicolumn{5}{|c|}{ Ground } \\
\hline Metal & $\begin{array}{l}\text { Result } \\
(\mathbf{m g} / \mathbf{L})\end{array}$ & Desv. Standar & $\begin{array}{c}\text { Result } \\
(\mathbf{m g} / \mathbf{g} \\
\text { rubber })\end{array}$ \\
\hline $\mathrm{Zn}$ & 22.155 & 1.582 & 23.263 \\
\hline $\mathrm{Cu}$ & 0.035 & 0.013 & 0.037 \\
\hline $\mathrm{Cr}$ & 0.727 & 0.0612 & 0.763 \\
\hline $\mathrm{Pb}$ & 0.032 & 0.0104 & 0.034 \\
\hline $\mathrm{Cd}$ & 0.051 & 0.004 & .054 \\
\hline $\mathrm{Fe}$ & 7.192 & 0.0165 & 7.552 \\
\hline $\mathrm{Ni}$ & 0.273 & 0.0126 & 0.287 \\
\hline
\end{tabular}

Table 3 Amount of metals obtained in a sample of ground rubber

Source: Self Made

ISSN: 2410-3462

ECORFAN® All rights reserved
Obtaining a high level of Zinc ( $\mathrm{Zn}$ ) of $23.26 \mathrm{mg}$ for each gram of ground rubber, Iron (Fe) $7.55 \mathrm{mg}$ for each gram of crushed rubber, and a high level of Copper $(\mathrm{Cu})$ of $0.037 \mathrm{mg}$ for each gram of ground rubber. .

On the other hand, within the design of the solar heater and the simulation of each piece, with the support of the SolidWork 2018 program, the following parts of the prototype, to be subjected to conditions of temperature, convection and ambient temperature.

Thermal rubber and alloyed metal: The piece "tubes" constituted by three tubes with 10 mm thickness each, on this occasion, the outer tube was limited with "rubber" and the two internal tubes with "unalloyed metal" under the following conditions:

\section{- $\quad$ Temperature: $360^{\circ} \mathrm{K}\left(86.85^{\circ} \mathrm{C}\right)$ \\ - Convection: $250 \mathrm{~W} / \mathrm{m}^{2} \mathrm{~K}$ \\ - $\quad$ Ambient temperature: $300^{\circ} \mathrm{K}\left(26.85^{\circ} \mathrm{C}\right)$ - $\quad$ Heat flow: $3500 \mathrm{~W} / \mathrm{m}^{2}$}

According to figure 2, there are high reddish tones on the external part of the tubes, especially a redder hue on the external face of the rubber tube (outer tube) representing temperatures greater than $360^{\circ} \mathrm{K}\left(86.85^{\circ} \mathrm{C}\right)$. and a bluish hue in the lower part of the rubber tube (external tube) giving reference to the insulator that this material represents; on the other hand, the two internal unalloyed metal tubes represent a reddish hue with a value greater than $355^{\circ} \mathrm{K}$ $\left(81.85^{\circ} \mathrm{C}\right)$, representing the high temperatures of the combination of these materials.

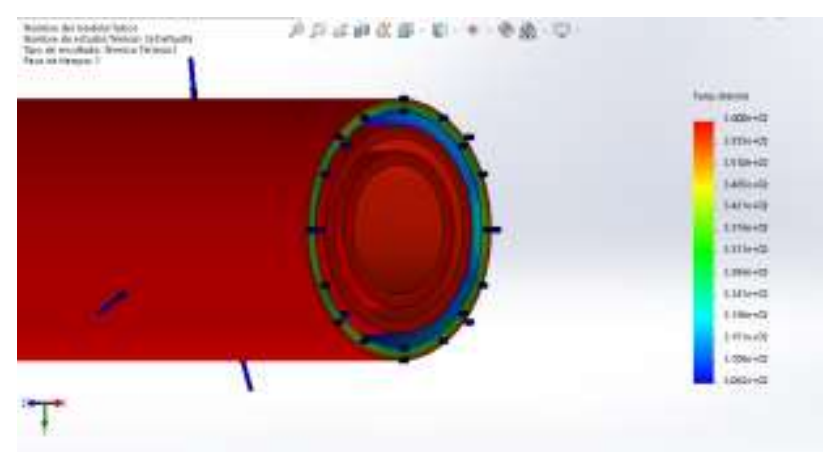

Figure 2 Analysis of heat flow in tubes of solar heater with rubber and metal

Source: self made

Thermal rubber: The "box" piece on this occasion was bounded with the "rubber" material in its entirety, visualizing the behavior of the material in terms of temperature incorporating the following conditions:

AGUILAR-PÉREZ, Silvia-Madai, SANCHEZ-RUIZ Francisco-Javier and AGUILAR-PÉREZ Esmeralda. Characterization and simulation of rubber derived from tire recycling as a proposal in the development of a solar heater. Journal Simulation and Laboratory. 2021 
- $\quad$ Temperature: $360^{\circ} \mathrm{K}\left(86.85^{\circ} \mathrm{C}\right)$

- Convection: $250 \mathrm{~W} / \mathrm{m}^{2} \mathrm{~K}$

- $\quad$ Ambient temperature: $300^{\circ} \mathrm{K}\left(26.85^{\circ} \mathrm{C}\right)$

- $\quad$ Heat flow: $3500 \mathrm{~W} / \mathrm{m}^{2}$

According to figure 3, the behavior of the "rubber" material in the box is represented as an insulator in its entirety, showing two shades of blue with temperatures from $36^{\circ} \mathrm{K}$ to $40^{\circ} \mathrm{K}$, thus demonstrating the behavior of the rubber material as main insulator in this prototype.

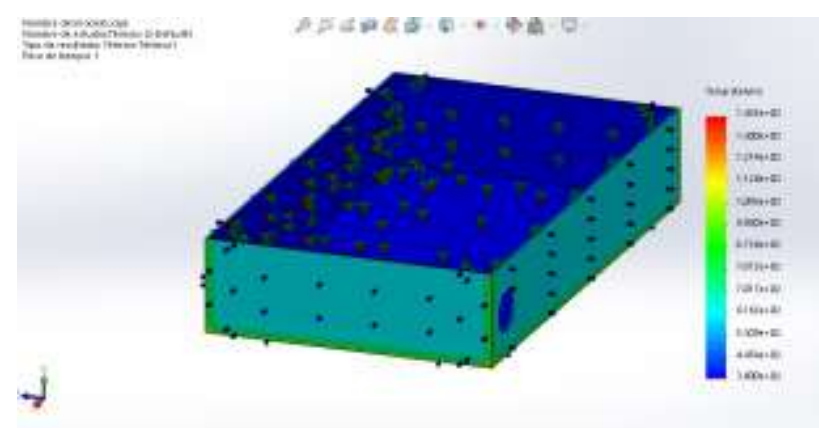

Figure 3 Rubber Case Heat Flow Analysis Source: Self Made

Thermal rubber and metal: The piece "polygon with openings " (first storage tank of the solar heater), this time it was limited with the "rubber" material in the internal tube that contains this tank, and in the external part with the "unalloyed metal" material for the rest of the solid, visualizing the behavior of the material in terms of temperature incorporating the following conditions:

\footnotetext{
- $\quad$ Temperature: $360^{\circ} \mathrm{K}\left(86.85^{\circ} \mathrm{C}\right)$

- Convection: $250 \mathrm{~W} / \mathrm{m}^{2} \mathrm{~K}$

- $\quad$ Ambient temperature: $300^{\circ} \mathrm{K}\left(26.85^{\circ} \mathrm{C}\right)$

- Heat flow: $3500 \mathrm{~W} / \mathrm{m}^{2}$
}

According to figure 4, the behavior of the "rubber" material behaves as the main insulator, seeing the behavior of the tube on the outside, with a reddish hue with temperatures higher than $360^{\circ} \mathrm{K}\left(86.85^{\circ} \mathrm{C}\right)$ and on the inside of the tube with a bluish hue reaching temperatures from $320^{\circ} \mathrm{K}\left(46.85^{\circ} \mathrm{C}\right)$; on the other hand, the polygon (tank) shows its behavior by the material "metal that was incorporated, exceeding temperatures above $360^{\circ} \mathrm{K}\left(86.85^{\circ} \mathrm{C}\right)$ with a greater area in quantity of heat..

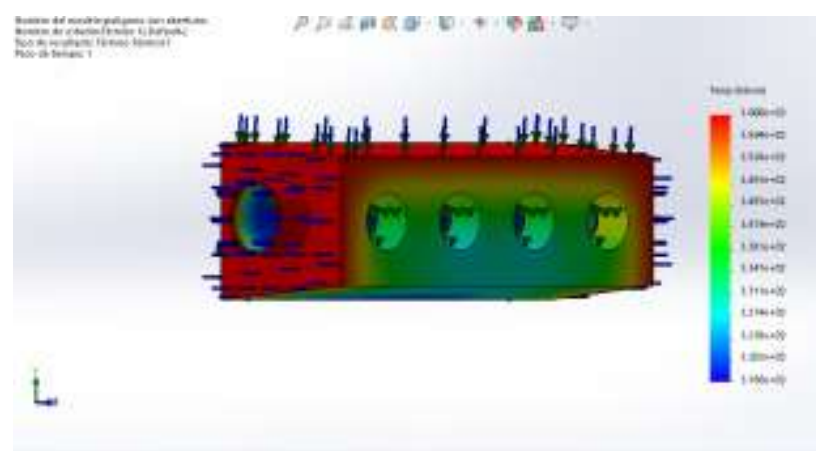

Figure 4 Polygon heat flow analysis with openings (tank) made of rubber and metal Source: Self Made

Thermal rubber: The piece "connecting tube" (first connection pipe to the system), in this occasion was limited with the material "rubber" in its entirety under the following conditions:

\section{- $\quad$ Temperature: $360^{\circ} \mathrm{K}\left(86.85^{\circ} \mathrm{C}\right)$ \\ - Convection: $250 \mathrm{~W} / \mathrm{m}^{2} \mathrm{~K}$ \\ - $\quad$ Ambient temperature: $300^{\circ} \mathrm{K}\left(26.85^{\circ} \mathrm{C}\right)$ \\ - Heat flow: $3500 \mathrm{~W} / \mathrm{m}^{2}$}

According to figure 5, the behavior of the "rubber" material behaves as the main insulator, seeing the behavior of the tube on the outside, with a reddish hue with temperatures higher than $360^{\circ} \mathrm{K}\left(86.85^{\circ} \mathrm{C}\right)$ and on the inside of the tube with a bluish hue reaching temperatures from $320^{\circ} \mathrm{K}\left(46.85^{\circ} \mathrm{C}\right)$

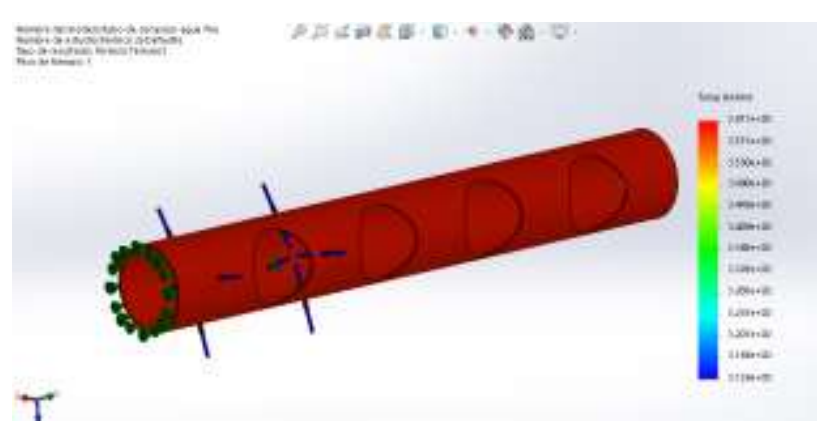

Figure 5 Rubber water connection pipe Source: Self Made

\section{Gratitude}

The most sincere gratitude is extended to the Popular University of the State of Puebla for the access to the facilities and the execution of this project, to the National Council of Science and Technology for the scholarship number 2020000026-02NACF-09666 awarded for the master's degree in Environmental Engineering and Sustainable Development at UPAEP. 
And at Thanks to the Higher Technological Institute of San Martín Texmelucan for the financing for the publication of this research article, and to the Popular University of the State of Puebla for access to the facilities for the research and execution of the project

\section{Conclusions}

The design of the solar heater in its composition of rubber derived from the recycling of the tire is a proposal for the use of this material, taking advantage of the thermal characteristics that it presents for the conservation of temperature in the water, when used in a solar tube heater system. vacuum, replacing materials such as glass and copper, which generate an increase in costs, with this material and verifying the viability of using recycled tire rubber. This research is in progress, with significant advances to be presented in the next publication, with the aim of studying the efficiency of the use of tire recycling materials through of the temperature gradient as a function of residence time.

\section{References}

Chevez (2018). Renewable energies and efficiency energy: Analysis of measures aimed at the residential sector.Repository Institutional

Din AT, Mohd Hafiz N. and Mohd Rus AZ (2018). Exploration to find green building materials from recycled solid wastes.

Journal of Advanced Research in Fluid Mechanics and Thermal Sciences, 47(1), 35-44.

Española A. (2020). The wheel, progress and eco-problem (p.10). https://www.tnu.es/recurso/pagina/archivo/tnu_ expo.pdf

Forbes (2015). Old tires cause 50\% of the car accidents. Forbes Staff. Available at: https://www.forbes.com.mx/llantasviejas-

causan-50-de-los-accidentes-deauto/

\#: :text=La\%20estad\%C3\%ADstica\%

20aparece\% 20en\% 20un, States \% 20Uni two\% 2C\% 20Europe\% 20y\% 20Asia. Accessed: October 15, 2021.
González L., Lu J., Rivera A. and Cedeño M. (2019). Waste tire volume estimation and reuse alternatives. Initiation Magazine Scientific, 4(2), 40-43.

https://doi.org/10.33412/revric.v4.2.2150

INEGI. (2016). Results presentation. https://www.inegi.org.mx/contenidos/prog branches / ccpv / 2020 / doc / cpv2020_pres_res_p ue.pdf

Jitjack K., Thepa S., Sudaprasert K. and Namprakai P. (2016). Improvement of a Rubber Drying Greenhouse with a parabolic cover and enhanced panels. Energy and Buildings http://dx.doi.org/10.1016/j.enbuild.2016.04030

Mujal Rosas M., Marín Genescà M., García Amorós J., Colom Fajula X. y Salueña B. (2018). Comparison of the mechanical and dielectric characteristics of various polymers mixed with rubber from out-of-use tires (GTR) for application as insulation for industrial work footwear. Master's Thesis. Universidad politécnica del centro Tabasco. file://C:/Users/Ruby/Downloads/MAESTRIA/ TESIS/acervo\%20bibliografico/Nuevos\%20arti culos/ARTICULO+DYNA+POLIMEROS+201 9-2\%20(1).pdf

Norambuena-Contreras J., Conchaa J. L. y Borinaga-Treviño R. (2017). Evaluación de las propiedades termofísicas y térmicas de una membrana de caucho compuesto con fines de captación de energía. Ensayos de polímeros. Evaluation of the thermophysical and heating properties of a composite rubber membrane with energy harvesting purposes. Polymer Testing 64, 145-155.

https://doi.org/10.1016/j.polymertesting.2017.0 9.042

Ortiz Rodríguez N.M., Marín Camacho J.F., González A.L., García Valladares O. (2020). Cinética de secado de láminas de caucho natural bajo dos sistemas de secado solar térmico, Energías

Renovables.https://doi.org/10.1016/j.renene.202 0.11.035.

Ospina, V. H. (2019). The tires are a real attack on the environment. GrupoEcoreproducts. https://ecoreproducts.com/grandescontaminates/ 
Pannucharoenwong N., Rattanadecho P., Timchenko V., Echaroj S. y Nabudda K. (2016). Aplicación de absorbente de calor de aluminio y caucho negro para destilación a base solar con configuración de doble vidrio inclinado. Revista de ciencia y tecnología de Asia y el Pacífico Application of aluminum and black rubber heat absorber for solar-base distillation with double slanted- glassed configuration., 24(3), 15-27. https://doi.org/https://www.tci-

thaijo.org/index.php/APST/index

Peláez Arroyave G. J., Velásquez Restrepo S. M. y Giraldo Vásquez D. H., (2017) Aplicaciones del caucho reciclado: revisión de la literatura. Ciencia e Ingeniería Neogranadina Applications of recycled rubber: a literature review. Neogranadina Science and Engineering, 27, 2, 27-50. http:// dx.doi.org/10.18359/rcin.2143

Química. (2018). Caucho Natural (p. 2). Pontifical Catholic University of Chile. http://quimica.uc.cl/images/paginas/fcauchonat uralsintetico.pdf

Razmilic B. (2021) FAO. Spectroscopy atomic absorption. Merck Química Chilena Soc. Ltda. $h$ ttps://www.fao.org/3/ab482s/ab482s04.htm

Rubio-Ramirez C.R., Martheyn-Lizarazo G. y Vera L. E. (2019). Metodología para el cálculo del rendimiento térmico de turbuladores helicoidales en calderas de vapor: modelo matemático y simulación. Scientia et Technica. 24, 03. Technological University of Pereira. file://C:/Users/Ruby/Downloads/Dialnet-

MetodologiaParaElCalculoDelDesempenoTerm icoDeTurbu-7101964.pdf

Sopian K., Sahari J., Othman M.Y., Zulkifly A. (1994). Monitorización del rendimiento de un calentador de agua solar de termosifón con un absorbedor de tubo de caucho natural termoplástico paralelo. Renovar Energía. 4 561577

Secretaría de Energía (2018). Performance thermal, gas savings and safety requirements of solar water heaters and solar water heaters backed by a water heater that uses LP gas or natural gas as fuel. Specifications, test methods and labeling. (NOM-027-ENER/SCFI-2018) Official Gazette of the Federation junuary 2018.
Secretaría de Salud (1995). Determination of cadmium, arsenic, lead, tin, copper, iron, zinc and mercury in food, drinking water and water purified by atomic absorption spectrometry. NOM-117-SSA1-1994. Official Gazette of the Federation No. 12, 16 August de 1995.

Tsilingiris P.T. (2000). Análisis de transferencia de calor de absorbedores de energía solar de baja conductividad térmica. Aplicar energía térmica Heat transfer analysis of low thermal conductivity solar energy absorbers. Apply Thermal Energy. 20. 20 1297-1314.

UNL. (junuary 2019). Special Handling Waste (RME). University of Nuevo León. Retrieved July 2, 2021 from http://sds.uanl.mx/residuosde-manejo-especial-rme/ 